ZUSES

In Cooperation with the New Mexico Interstate Stream Commission

\title{
Estimates of Mean-Annual Streamflow and Flow Loss for Ephemeral Channels in the Salt Basin, Southeastern New Mexico, 2009
}

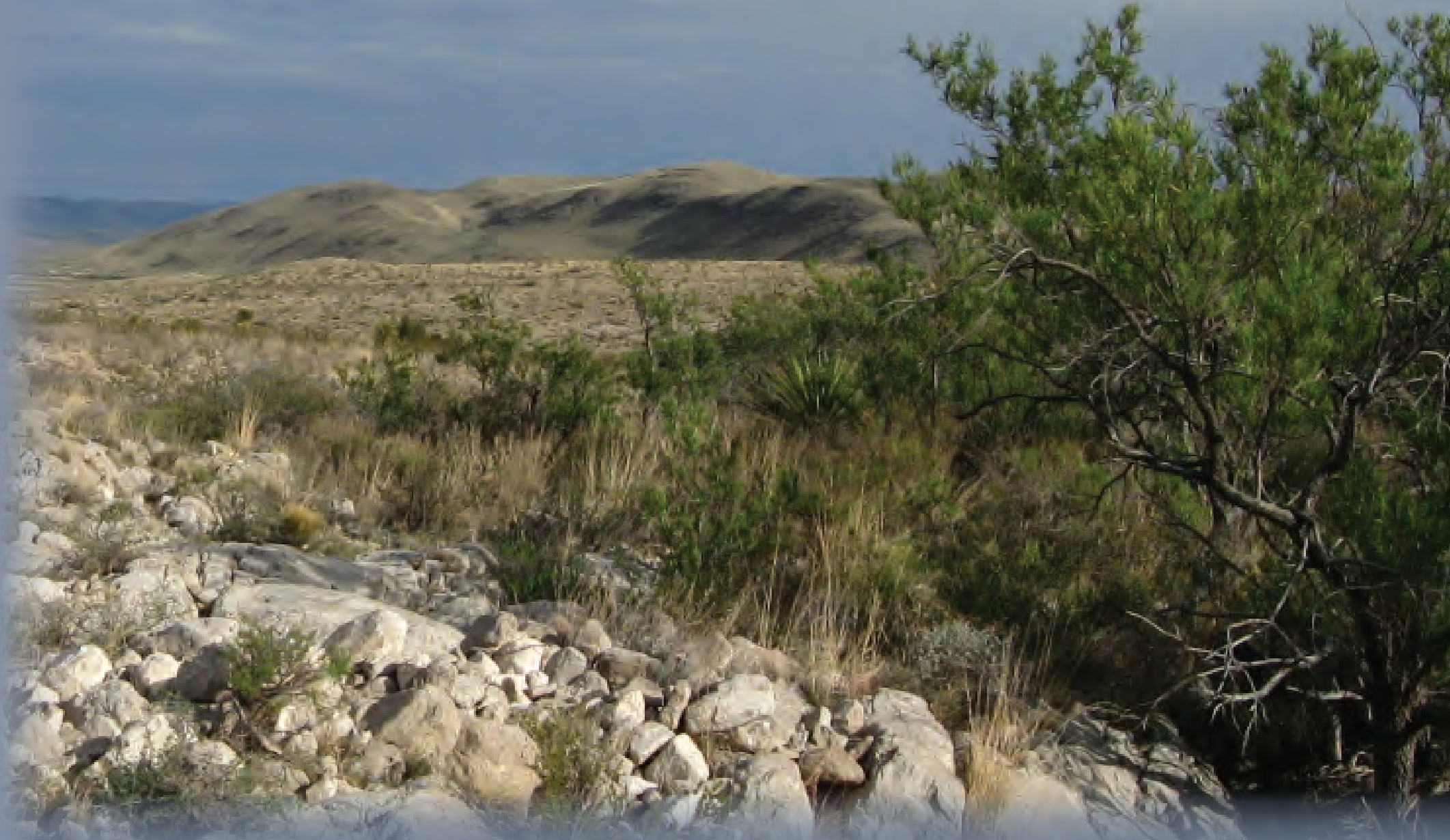

Scientific Investigations Report 2011-5062 



\section{Estimates of Mean-Annual Streamflow and Flow Loss for Ephemeral Channels in the Salt Basin, Southeastern New Mexico, 2009}

By Anne Tillery

In Cooperation with the New Mexico Interstate Stream Commission

Scientific Investigations Report 2011-5062

U.S. Department of the Interior

U.S. Geological Survey 


\title{
U.S. Department of the Interior \\ KEN SALAZAR, Secretary \\ U.S. Geological Survey \\ Marcia K. McNutt, Director
}

\section{U.S. Geological Survey, Reston, Virginia: 2011}

\author{
This and other USGS information products are available at http://store.usgs.gov/ \\ U.S. Geological Survey \\ Box 25286, Denver Federal Center \\ Denver, CO 80225 \\ To learn about the USGS and its information products visit http://www.usgs.gov/ \\ 1-888-ASK-USGS
}

\begin{abstract}
Any use of trade, product, or firm names is for descriptive purposes only and does not imply endorsement by the U.S. Government.

Although this report is in the public domain, permission must be secured from the individual copyright owners to reproduce any copyrighted materials contained within this report.
\end{abstract}

Suggested citation:

Tillery, Anne, 2011, Estimates of mean-annual streamflow and flow loss for ephemeral channels in the Salt Basin, southeastern New Mexico, 2009: U.S. Geological Survey Scientific Investigations Report 2011-5062, 20 p. 


\section{Contents}

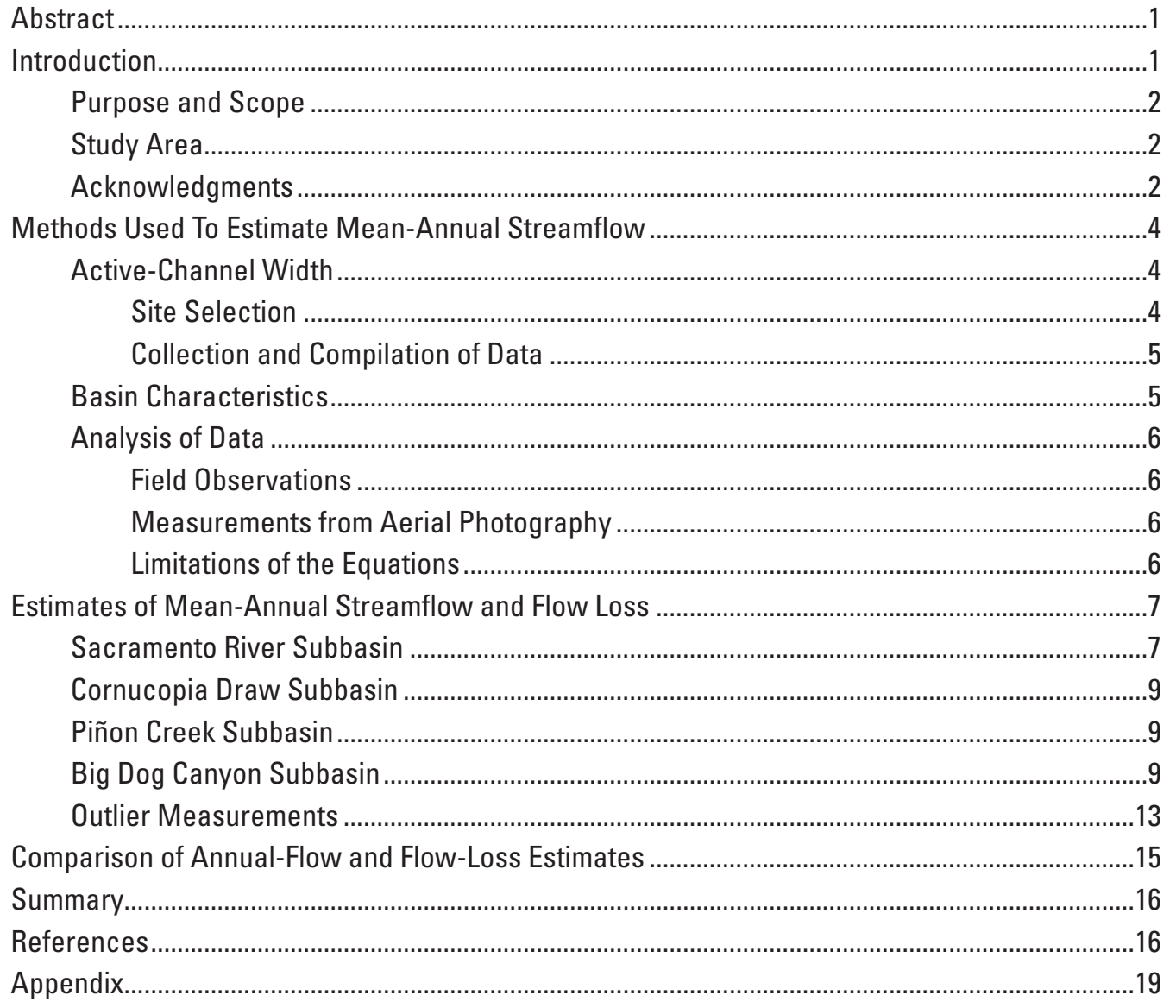

\section{Figures}

1. Salt Basin study area in southeastern New Mexico showing location of surface-water subbasins measured for this study......................................................

2. Typical channel cross section in the northern Salt Basin, N. Mex.................................5

3. Typical substrate material of ephemeral channels in the northern Salt Basin, N. Mex.

4. Histogram of percent error in remote channel-geometry measurements for 52 sites in the Salt Basin, N. Mex.

5. Log-log scatter plot comparing basin area to active-channel width for all 52 sites measured in the Salt Basin, N. Mex.

6. A, Estimates of mean-annual streamflow for eachSacramento River, N. Mex., subbasin site displayed categorically by increasing basin area. $B$, Sacramento River subbasin. $C$, Trends of mean-annual streamflow estimates compared to basin area for the two methods used at the study sites in the Sacramento River, N. Mex., subbasin 
7. A, Estimates of mean-annual streamflow for each Cornucopia Draw, N. Mex., subbasin site displayed categorically by increasing basin area. $B$, Cornucopia Draw subbasin. $C$, Trends of mean-annual streamflow estimates compared to basin area for the two methods used at the study sites in the Cornucopia Draw, N. Mex., subbasin.

8. A, Estimates of mean-annual streamflow for each Piñon Creek, N. Mex., subbasin site displayed categorically by increasing basin area. $B$, Piñon Creek subbasin. $C$, Trends of mean-annual streamflow estimates compared to basin area for the two methods used at the study sites in the Piñon Creek, N. Mex., subbasin

9. Typical Big Dog Canyon, N. Mex., channel section

\section{Tables}

1. Sacramento River, N. Mex., active-channel widths and mean-annual streamflow estimates.

2. Cornucopia Draw, N. Mex., active-channel widths and mean-annual streamflow estimates

3. Piñon Creek, N. Mex., active-channel widths and subbasin mean-annual streamflow estimates

4. Big Dog Canyon, N. Mex., active-channel widths and mean-annual streamflow estimates

5. Southeastern New Mexico outlier active-channel widths and mean-annual streamflow estimates

6. Basin characteristics associated with location of maximum active-channel width in each of the main subbasins measured in southeastern New Mexico.

7. Flow losses and associated distances for the four main subbasins studied in southeastern New Mexico. 


\section{Conversion Factors}

Inch/Pound to SI

\begin{tabular}{|c|c|c|}
\hline Multiply & By & To obtain \\
\hline \multicolumn{3}{|c|}{ Length } \\
\hline inch & 25.40 & millimeter $(\mathrm{mm})$ \\
\hline foot $(\mathrm{ft})$ & 0.3048 & meter $(\mathrm{m})$ \\
\hline mile (mi) & 1.609 & kilometer $(\mathrm{km})$ \\
\hline \multicolumn{3}{|c|}{ Area } \\
\hline acre & 4,047 & square meter $\left(\mathrm{m}^{2}\right)$ \\
\hline acre & 0.4047 & hectare (ha) \\
\hline acre & 0.4047 & square hectometer $\left(\mathrm{hm}^{2}\right)$ \\
\hline acre & 0.004047 & square kilometer $\left(\mathrm{km}^{2}\right)$ \\
\hline square mile $\left(\mathrm{mi}^{2}\right)$ & 259.0 & hectare (ha) \\
\hline square mile $\left(\mathrm{mi}^{2}\right)$ & 2.590 & square kilometer $\left(\mathrm{km}^{2}\right)$ \\
\hline \multicolumn{3}{|c|}{ Volume } \\
\hline acre-foot (acre-ft) & 1,233 & cubic meter $\left(\mathrm{m}^{3}\right)$ \\
\hline acre-foot (acre-ft) & 0.001233 & cubic hectometer $\left(\mathrm{hm}^{3}\right)$ \\
\hline \multicolumn{3}{|c|}{ Flow rate } \\
\hline acre-foot per day (acre-ft/d) & 0.01427 & cubic meter per second $\left(\mathrm{m}^{3} / \mathrm{s}\right)$ \\
\hline acre-foot per year (acre-ft/yr) & 1,233 & cubic meter per year $\left(\mathrm{m}^{3} / \mathrm{yr}\right)$ \\
\hline cubic foot per second $\left(\mathrm{ft}^{3} / \mathrm{s}\right)$ & 0.02832 & cubic meter per second $\left(\mathrm{m}^{3} / \mathrm{s}\right)$ \\
\hline $\begin{array}{l}\text { cubic foot per second per square } \\
\text { mile }\left[\left(\mathrm{ft}^{3} / \mathrm{s}\right) \mathrm{mi}^{2}\right]\end{array}$ & 0.01093 & $\begin{array}{l}\text { cubic meter per second per } \\
\text { square kilometer }\left[\left(\mathrm{m}^{3} / \mathrm{s}\right) / \mathrm{km}^{2}\right]\end{array}$ \\
\hline
\end{tabular}

Vertical coordinate information is referenced to the North American Vertical Datum of 1988 (NAVD 88).

Horizontal coordinate information is referenced to the North American Datum of 1983 (NAD 83).

Altitude, as used in this report, refers to distance above the vertical datum. 



\title{
Estimates of Mean-Annual Streamflow and Flow Loss for Ephemeral Channels in the Salt Basin, Southeastern New Mexico, 2009
}

\author{
By Anne Tillery
}

\section{Abstract}

As much as 57 million acre-feet of groundwater may be stored in the subsurface of the New Mexico part of the Salt Basin in southern Otero County, N. Mex. Recharge to a system such as the Salt Basin aquifer can result largely from focused recharge of surface water in channels and at mountain fronts. The Salt Basin is a closed basin that covers about 2,400 square miles of southeastern New Mexico and continues across the State line into Texas. A graben underlies the central valley, which is buried by hundreds of feet of alluvial deposits. Bedrock that underlies the alluvial deposits and forms the surrounding plateaus is composed primarily of carbonate and mixed carbonate/evaporate units that can be karst forming in places. Karst features in the downstream parts of some areas of the Salt Basin also may provide opportunities for substantial recharge. Annual recharge to an aquifer such as the Salt Basin aquifer is commonly estimated in groundwater models by mean-annual streamflow. In 2009, the U.S. Geological Survey (USGS), in cooperation with the New Mexico Interstate Stream Commission, estimated mean-annual streamflow for selected channels in the Salt Basin.

Mean-annual streamflow was estimated for four main subbasins in the internally drained Salt Basin in southeastern New Mexico. These four main subbasins account for 30 percent of the Salt Basin area in New Mexico. Estimates of mean-annual streamflow were generated at multiple sites down the length of each basin by using two regional regression equations based on channel geometry and one based on the basin characteristics of area and precipitation. Results indicate that, on average, an estimated 60,414 acre-feet of flow is generated annually among the four main subbasins in the New Mexico part of the Salt Basin.

The use of the channel-geometry method at multiple locations down the length of each channel also provided information on the locations of flow accumulation and losses. By contrast, application of the basin-characteristics method will always produce increased runoff estimates with downstream distance in a single basin; therefore, the method is not sensitive to flow losses. Channels that were measured achieved maximum active-channel widths from 6 to 16 stream miles upstream from the locations in which channels bifurcate and lose shape altogether when they reach the lowlands of the internally drained basin. Active-channel-width measurements indicate that each of the four main subbasin channels studied loses between 27 and 56 percent of annual flow from the point of maximum active-channel width to the most downstream measureable section in the channel.

\section{Introduction}

As much as 57 million acre-feet (acre-ft) of groundwater may be stored in the subsurface of the New Mexico part of the Salt Basin in southern Otero County, N. Mex. Of this groundwater, 15 million acre-ft is potentially recoverable and potable (Livingston Associates and John Shomaker and Associates, 2002); however, a better understanding of the water budget hydrologic processes occurring in the Salt Basin would allow for the most effective management of these resources.

As documented by Huff and Chace (2006), much previous work has been conducted to describe groundwater conditions in the Salt Basin, and despite the large number of studies, groundwater-recharge estimates remain wide ranging. Recharge to a system such as the Salt Basin aquifer can result largely from focused recharge of surface water in channels and at mountain fronts (Anderholm, 2000); however, karst and fractured-rock features in the downstream parts of some of the basins also may provide opportunities for substantial recharge. Mean-annual streamflow is commonly used in groundwater models as an estimate of the potential annual recharge to an aquifer (Waltemeyer, 2001). Characterization of mean-annual streamflow would, therefore, be an important contribution to estimates of potential recharge for the Salt Basin aquifer. In 2009, the U.S. Geological Survey (USGS), in cooperation with the New Mexico Interstate Stream Commission (ISC), estimated mean-annual streamflow for selected channels in the Salt Basin. 
Conventional streamflow-gaging stations can be used to obtain mean-annual streamflow, but it takes many years of data collection to establish a reliable estimate. The karst and fractured-rock features that dissect parts of the Salt Basin may affect channel-flow losses and groundwater recharge. Determination of channel flow in the Salt Basin at any one point along a reach does not provide information about flow losses upstream, downstream, or in the overbank areas of that reach. It would, therefore, take installation of numerous streamgages in each channel to address the question of flow loss.

Because direct methods of measuring the annual surface-water flow for the entire Salt Basin are not practical (prohibitively expensive), indirect methods were applied. Two indirect methods applied were based on channel geometry, and one method was based on the basin characteristics of area and precipitation. Although the use of basin characteristics to estimate flow is common, the method of estimating long-term streamflow characteristics based on channel geometry also has been applied in numerous studies in the United States since the 1950s (Wahl, 1984). The channel-geometry method is based on the principle that channel-geometry characteristics, such as channel width, are determined or altered by forces operating within the channel over an extended period of time.

Precipitation increases with elevation in the desert Southwest; therefore, the higher elevation subbasins of the Salt Basin, such as the Sacramento River subbasin, have greater runoff and potential for greater recharge. Although some channelized flow is probably lost through evapotranspiration, the short streamflow duration of the ephemeral channels may limit these losses. If evapotranspiration losses in the channels are minimal, the total mean-annual runoff from ephemeral channels in the Salt Basin can be considered a maximum potential basin recharge. Application of the channel-geometry method in multiple locations down the length of the stream can provide information on where annual flow is decreasing downstream and where recharge might be concentrating.

\section{Purpose and Scope}

This report presents estimates of mean-annual streamflow and flow loss of select, representative, ephemeral surfacewater channels in the Salt Basin. The channels evaluated in this study were mainly contained in four main subbasins of the Salt Basin. Estimates were calculated by using separate regional regression equations developed on the basis of channel-geometry measurements and basin and climatic characteristics. Channel losses were identified as decreases in annual-flow estimates in downstream reaches compared with upstream reaches. The study area is the part of the Salt Basin that lies within New Mexico.

\section{Study Area}

The Salt Basin (fig. 1) is a closed basin that covers about 2,400 square miles $\left(\mathrm{mi}^{2}\right)$ of southeastern New Mexico and continues across the State line into Texas. The New Mexico part of the basin is bounded to the north by the Sacramento Mountains, to the east by a steep westward-facing escarpment that grades into the Guadalupe Mountains, and to the west by the Otero Mesa. A graben underlies the east-central valley, which is buried by as much as 750 feet (ft) of alluvial deposits. Bedrock that underlies the alluvial deposits and forms the surrounding plateaus is composed primarily of carbonate and mixed carbonate/evaporate units of Permian age (Huff and Chace, 2006).

Elevations in the Salt Basin range from 9,255 ft at Sacramento Peak to 3,600 ft in the dry salt flats 15 miles (mi) south of the New Mexico border. The precipitation varies widely throughout the study area depending on elevation. The higher elevations of the study area near Sacramento Peak receive 33 inches annually, 35 percent of which occurs during the winter months, likely in the form of snow. Snowmelt in the southern Sacramento Mountains sustains perennial streamflow in the Sacramento River at or near the mountain front. The lower elevations near the western base of the Guadalupe Mountains at the New Mexico-Texas border receive less than 9 inches of precipitation annually, most of which occurs as rainfall (PRISM Climate Group, 2009). The analysis conducted in this study focuses primarily on four main subbasins in the northern and eastern parts of the Salt Basin in New Mexico, three of which are considered mountain-front drainages (Piñon Creek, Sacramento River, and Big Dog Canyon).

\section{Acknowledgments}

Several people from the USGS New Mexico Water Science Center assisted in preparation of this report. Peter Bennett assisted with collection of field data. Roger Durall compiled geographic information system (GIS) data. Scott Waltemeyer provided guidance and advice on application of the method. Jack Veenhuis assisted with the precipitation-data analysis. Chuck Parrett of the USGS California Water Science Center provided a colleague review.

Steve Finch of John Shomaker and Associates also provided a colleague review. 


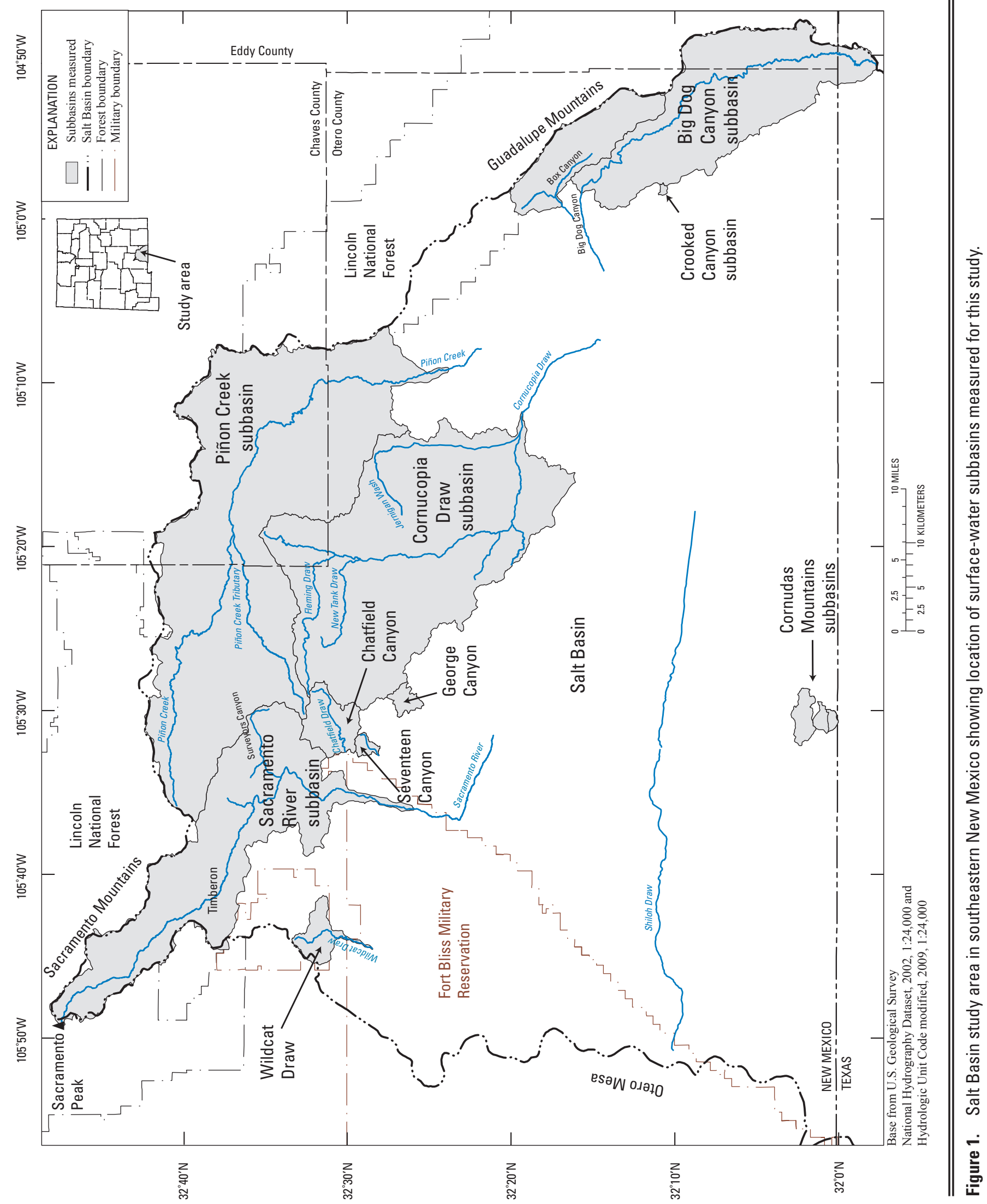




\section{Methods Used To Estimate Mean-Annual Streamflow}

For this study, mean-annual streamflow was estimated at various locations on ephemeral channels in the Salt Basin by using multiple methods, each of which was initially established for estimating mean-annual streamflow specifically for channels in New Mexico. Two of the methods are based on channel geometry, specifically active-channel width, and one method is based on the basin characteristics of area and precipitation. The active-channel-width methods used include a relation for estimation of mean-annual streamflow developed by Waltemeyer (1993) for mountain-front channels in southern New Mexico and a relation for estimation of mean-annual streamflow developed by Kunkler and $\operatorname{Scott}^{1}$ (Waltemeyer, 1993) for channels throughout the State of New Mexico.

Waltemeyer used active-channel width (W) in feet to estimate mean-annual streamflow $\left(\mathrm{Q}_{\mathrm{a}}\right)$ in cubic feet per second as follows:

$$
\mathrm{Q}_{\mathrm{a}}=0.04 \mathrm{~W}^{1.59}
$$

The Kunkler and Scott channel-geometry method (Waltemeyer, 1993) varies considerably in the weight assigned to the active-channel-width variable as follows:

$$
\mathrm{Q}_{\mathrm{a}}=1.59 \mathrm{~W}^{0.58}
$$

The basin-characteristics method used also was developed by Waltemeyer (1993) and is specific to mountainfront channels in southern New Mexico:

$$
\mathrm{Q}_{\mathrm{a}}=1.7 \times 10^{-4} \mathrm{~A}^{1.35} \mathrm{P}^{1.65}
$$

where

$$
\begin{aligned}
& \mathrm{A}=\text { drainage area, in square miles, and } \\
& \mathrm{P}=\text { mean-annual precipitation, in inches. }
\end{aligned}
$$

For this study, the channel-geometry annual-flow regression developed by Waltemeyer (1993) was selected to estimate flow. Waltemeyer's (1993) channel-geometry equation was selected because the regression equation was established by using mountain-front channels in southern New Mexico and also because, at 29 percent, the standard error of estimate for the regression equation is much lower than standard error of estimate for both the Kunkler and Scott (1976) equation ( 82 percent) and the regression equation developed for mountain-front basin characteristics (46 percent) (Waltemeyer, 1993).

\footnotetext{
${ }^{1}$ The original Kunkler and Scott report could not be located and may never have been published; however, the Kunkler and Scott mean annual flow regression equation is fully explained in Waltemeyer (1993).
}

\section{Active-Channel Width}

Many investigations of streamflow based on channel geometry have been conducted in the Western United States. Some of the more comprehensive investigations include Moore (1974), Hedman and Osterkamp (1982), Omang and others (1983), and Parrett and others (1987). Studies specific to New Mexico include Scott and Kunkler (1976), Hejl (1980), and Waltemeyer (1993, 2001). Summaries of the accuracy of channel-geometry measurements and the evolution of the channel-geometry method were published by Wahl $(1977,1984)$. Most of the previous studies were conducted to estimate flood-frequency discharges rather than mean-annual streamflows. No channel-geometry studies have been conducted in the Salt Basin.

Channel-width equations may provide more reliable estimates of mean-annual streamflow than do basincharacteristics equations in arid and semiarid regions where flow characteristics are often only poorly related to basin measurements (Hedman and Osterkamp, 1982; Wahl, 1984; Waltemeyer, 1993). Channel width generally reflects the prevailing streamflow and sediment-transport conditions at a site, regardless of the climatic conditions.

The channel-geometry method described in detail by Hedman and Osterkamp (1982) and used by Waltemeyer (1993) requires field measurement of active-channel width and characterization of channel-bed material to estimate mean-annual runoff. The technique requires selection of appropriate reaches and proper identification of the active channels in the field. In general, reaches selected need to be the following: at least three times the cross-section width in length, 100 percent natural, nonregulated, and formed entirely in alluvium (no bedrock exposed). Reaches with incoming tributaries, large pools or steep inclines, unusually shaped channel cross sections, and braided channels need to be avoided because such channel inconsistencies would invalidate the method. Because of these criteria, reaches that contained bedrock in the bed or banks, which were entirely vegetated (such as grassy draws), and braided-channel sections were eliminated. Additionally, the method is applicable only where channel morphologies are well defined. Geomorphic and ecologic indicators are used to identify active-channel width. The most prominent indicators are a break in slope between the steep slope of the channel bank and the gently sloping flood plain, ideally coinciding with the lower limit of permanent vegetation.

\section{Site Selection}

Specific locations for applying the channel-geometry method were selected during field reconnaissance and by analyzing aerial photographs prior to field work. Sites were selected on the basis of the specific criteria previously described and whether or not they were easily accessible. Multiple measurements were made down the length of each major channel, in addition to selected tributary channels, to 
provide information about where runoff accumulates and where channel losses occur.

Selection of reaches was challenging because of the prominence of braided-stream morphology in many of the channels and the grassy swales and draws in the southwestern part of the study area, neither of which are applicable to the channel-geometry method. It also was not possible to use the active-channel-width method in the most downstream reaches of all channels in the Salt Basin, because all of the channels tended toward braiding and bifurcation as they reached the flatter terrain in the lower elevations of the internally drained basin. Lack of appropriate channel conditions in the southwestern and south-central parts of the basin resulted in most measurement sites being located within four main subbasins: Sacramento River, Piñon Creek, and Big Dog Canyon, located in the mountain-front areas of the Sacramento and Guadalupe Mountains, and Cornucopia Draw, located in the limestone uplands just below the mountain-front areas (fig. 1).

Although selection of active-channel width in the field requires practice, identification of active-channel width in channels in the Salt Basin was fairly straightforward in most cases. The active-channel width was frequently defined by the lowest extent of permanent vegetation, which usually coincided with a change in slope from a steep one below the vegetation line to a shallower one above. Additionally, the clean gravel and cobbles in the channel beds provided a sharp visual contrast to the soil-rich overbank materials (fig. 2).

Each site was labeled according to (1) the subbasin name, (2) relative position as the sites were established downstream, and (3) whether the site was located on the main-stem channel or a tributary. Each site label begins with a four-letter abbreviation for the subbasin name followed by a two-digit number that increases in downstream order followed by another two-digit number to represent a tributary of the named

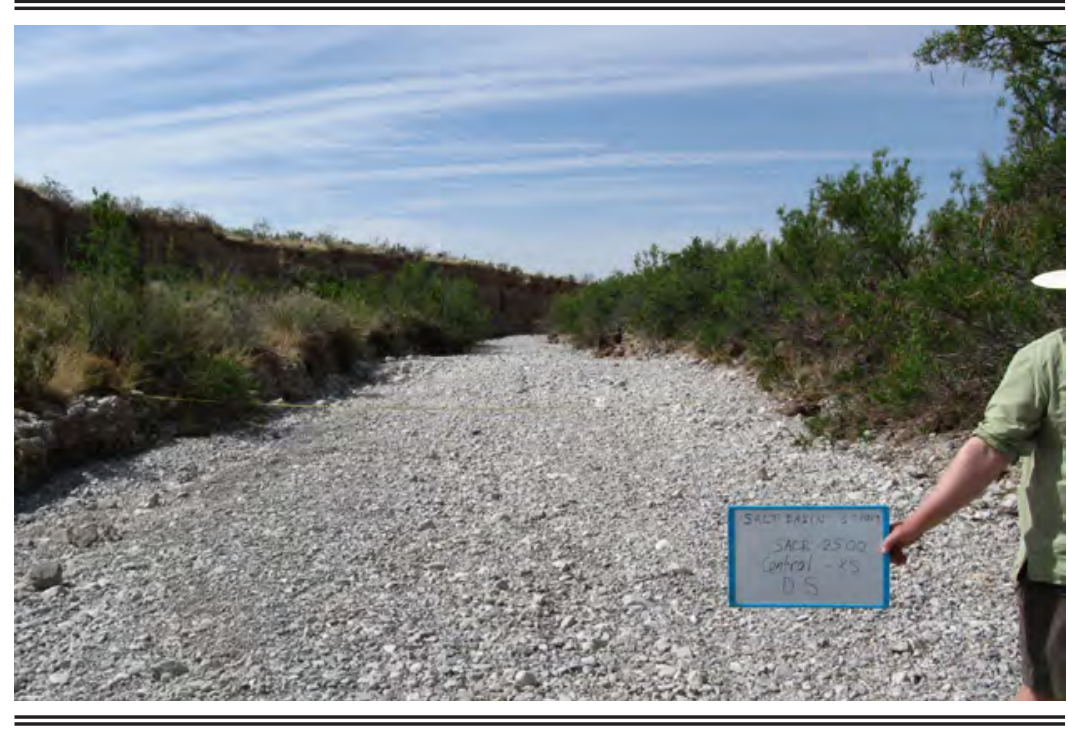

Figure 2. Typical channel cross section in the northern Salt Basin, N. Mex. (SACR-25.00 central cross section, facing downstream). subbasin or zeros to represent main-stem sites. For example a site on the main stem of Big Dog Canyon would be labeled BDOG-20.00. A tributary in the vicinity of that main-stem site would be labeled BDOG-20.05. The two-digit numbers generally increase by fives to allow room for the later addition of sites in between two previously measured sites.

\section{Collection and Compilation of Data}

Channel surveys were made at 10 sites in the Sacramento River subbasin, 8 in the Piñon Creek subbasin, 9 in the Big Dog Canyon subbasin, and 15 in the Cornucopia Draw subbasin, in addition to 10 in six other small subbasins (see appendix). Three measurements of active-channel width were made, one stream width apart, at all but two sites, where the reach length was not adequate. At each of three sites, one measurement was discarded after initial analysis because it was substantially different from the remaining two measurements at each of those sites. The two or three measurements made at each site were then averaged. Because the individual measurements at each site varied somewhat depending on natural channel-width variability, the precision of the average value was considered to be about two significant figures. For example, an average width of $9.86 \mathrm{ft}$ was reported as $9.9 \mathrm{ft}$, and an average width of $20.36 \mathrm{ft}$ was reported as $20 \mathrm{ft}$. The average active-channel-width value at each site was used in flow calculations. Photographs were taken facing upstream and downstream and of the substrate material at each site. A hand-held Global Positioning System (GPS) unit was used to record the coordinates of each measurement point.

After the general channel substrate and morphologies were established through field visits, making additional channel-geometry measurements remotely by using aerial photographs also was tested. The location of each field measurement was plotted on Google Earth (Google Earth, 2009), and channels were again measured by using the remote measuring tool provided on Google Earth (Google Earth, 2009). Remote measurements of active-channel width were compared with the field measurements.

\section{Basin Characteristics}

The basin-characteristics regression equation requires the input variables of basin area and mean-annual precipitation for each site. A geographic information systems (GIS) database was used to calculate these variables at each measurement site for active-channel width. The 1971-2000 mean-annual precipitation coverage created by the PRISM Climate Group (2009) data was used to calculate the weighted mean-annual precipitation for each basin. 


\section{Analysis of Data}

Mean-annual streamflow was estimated at each measurement location by using the two active-channel-width methods and one basin-characteristics method discussed.

\section{Field Observations}

Substrate materials of the ephemeral channels varied throughout the Salt Basin and consisted almost exclusively of clean, subangular to well-rounded gravel and cobbles at most of the sites measured (fig. 3). Grain size, rounding, and sorting of the material varied with downstream distance. Sand and (or) clay occasionally would be present in the channel beds but only in small percentages compared to the gravel and cobbles. The only exception to this observation was one site in the Cornudas Mountain area, where the channel bed is dominated by sand.

Because of the limestone source rock in the northern Salt Basin, the alluvial-channel beds tend to exhibit early stages of carbonate cementation. Carbonate cementation results in banks that are more resistant to horizontal weathering and, perhaps, more prone to incision or entrenchment than they might be in the absence of the carbonate. At some measurement sites, vertical-channel banks were as much as $3 \mathrm{ft}$ high. Generally, sites with deeply entrenched channels were avoided.

\section{Measurements from Aerial Photography}

Remote measurements of active-channel width determined from aerial photographs were poorly correlated with the field measurements and were determined to be an unsuitable substitute for field-data collection of active-channel width. From aerial photographs, it is not possible to see important channel features such as channel bars, channel braiding, and bedrock exposures that are critical to establishing the active-channel width. Additionally, riparian vegetation frequently obscures the channel banks from view in the aerial photographs. The error of aerial photograph measurements from field measurements of active-channel width ranged from -125 percent to +75 percent (fig. 4). Only 13 of 52 aerial-photograph measurements of active-channel width agreed within 10 percent of the field measurement. The aerial-photograph measurements with the lowest percent errors did not correspond to any particular magnitude of channel width. Of the 13 measurements with less than 10 percent error, the active-channel widths, measured in the field, ranged from 7.4 to $83 \mathrm{ft}$.

\section{Limitations of the Equations}

Regression equations may not provide reliable results when the variables are outside the range of values used to develop the equations. The established range of active-channel widths for the Waltemeyer (1993) channel-geometry method is $15-55 \mathrm{ft}$. Eight channels measured, mostly including small tributaries and two channels in Big Dog Canyon, have activechannel widths less than $15 \mathrm{ft}$. The three most downstream channel sections measured on Piñon Creek and one section measured on Sacramento River have active-channel widths greater than $55 \mathrm{ft}$.

The established range of basin areas for the basincharacteristics method is $20.7-184 \mathrm{mi}^{2}$. Twenty-five sites including several of the smaller tributaries on Cornucopia Draw and Sacramento River and some of the miscellaneous channels measured have basin areas less than $20.7 \mathrm{mi}^{2}$. The effect of this loss of sensitivity in the smaller basins generally results in low estimates of mean-annual streamflow and is evident in the plots of annual-flow estimates developed by the basin-characteristics method. The two most downstream sites on both Cornucopia Draw and Piñon Creek have basin areas larger than $184 \mathrm{mi}^{2}$. Annual precipitation values for the

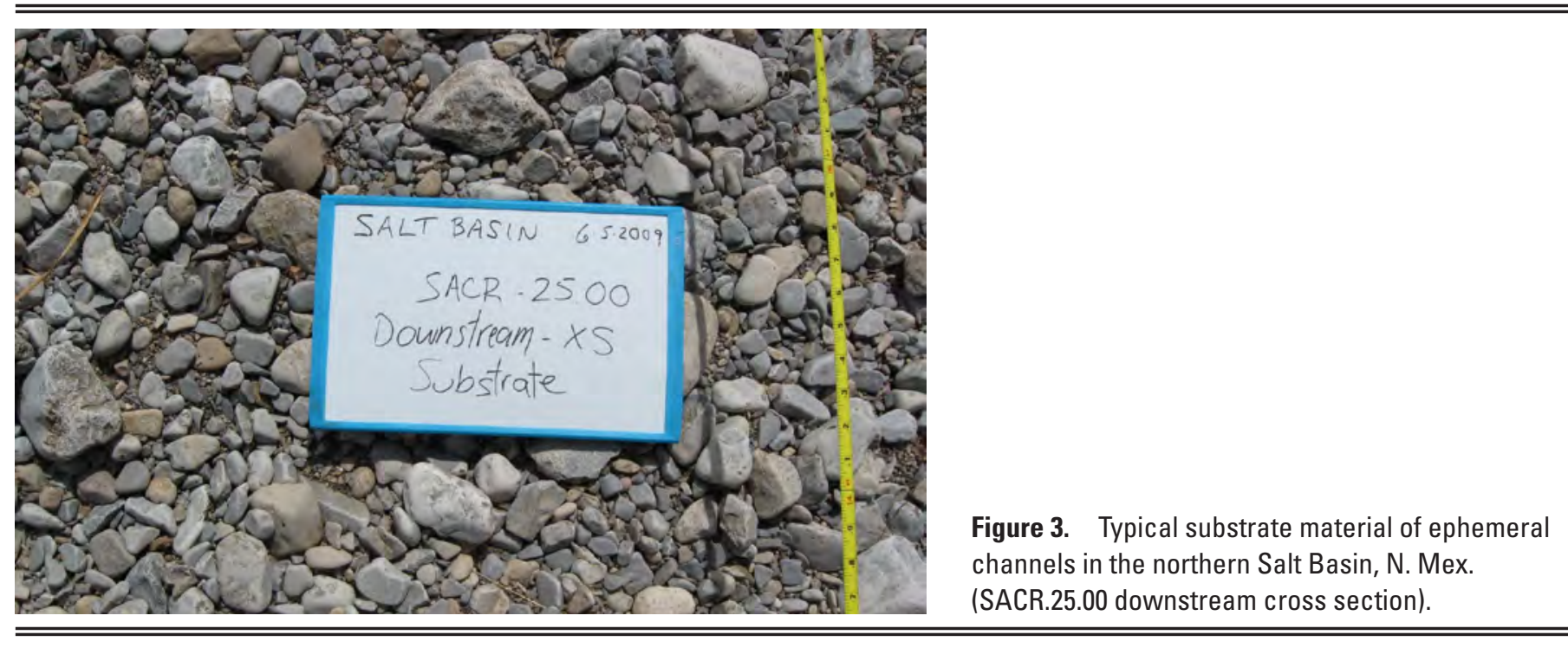




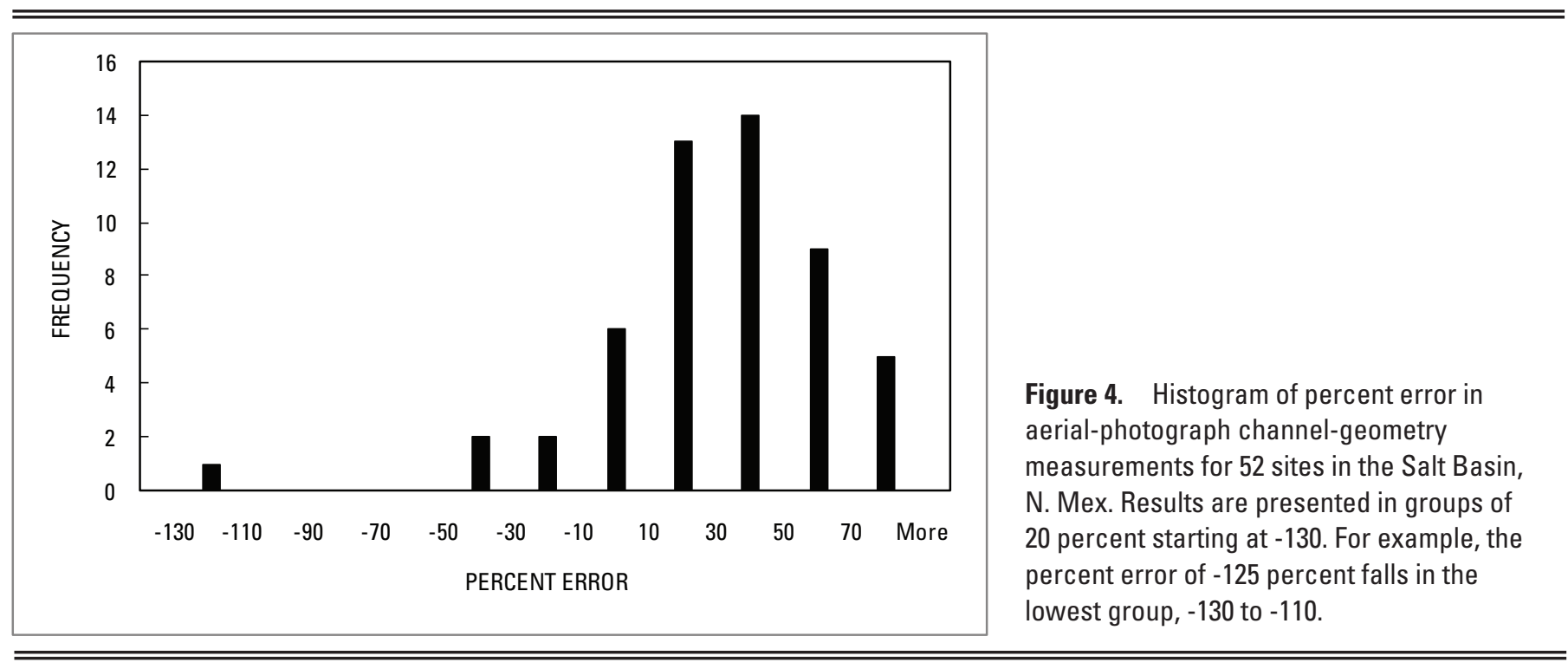

entire basin were within the range specified for the basincharacteristics equation.

\section{Estimates of Mean-Annual Streamflow and Flow Loss}

Initial analyses validate Wahl's (1984) observation that basin area is only poorly related to flow characteristics for channels in arid regions. Basin areas compared to activechannel widths for 52 sites measured in this study are presented in a log-log scatter plot in figure 5 .

Because the basin-characteristics equation relies on drainage area (A) and mean-annual precipitation $(\mathrm{P})$, and because precipitation does not vary greatly across these basins, the basin-characteristics regression-equation estimates always indicate increasing annual flow with increasing basin area (and consequently, downstream distance) in the Salt Basin. In contrast to the trend of increasing flow with downstream distance, the maximum active-channel width did not occur at the most downstream sections measured in any of the main subbasins studied. The maximum active-channel widths in each basin are located at an intermediate location some distance upstream from the farthest downstream section measured. In three of the four main subbasins studied, the measurements of active-channel width follow a pattern of increasing downstream from the headwaters to some maximum value and then decreasing again towards the most downstream channel reach measured. The results of the active-channel-width measurements and mean-annual streamflow estimates for the individual subbasins follow.

\section{Sacramento River Subbasin}

The active-channel width was measured at five locations on the Sacramento River (fig. 6) and at four sites on the tributary Surveyors Canyon and two other small tributaries. Initial analysis indicated that the measurement made at site SACR-20.00 was anomalously high. Further inspection of field notes and photographs indicated that site SACR-20.00 was less than ideal because of divided flow and insufficient length of reach; thus, the measurement was discarded. The active-channel widths and annual-flow estimates for the Sacramento River subbasin sites are shown in table 1.

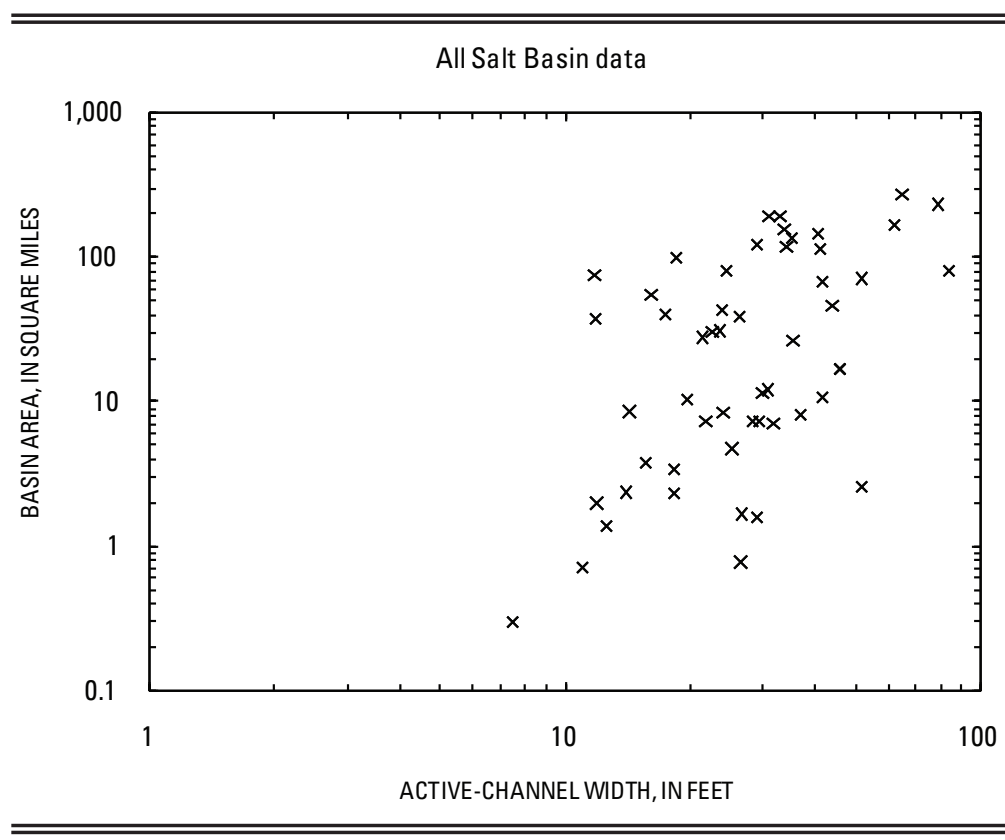

Figure 5. Log-log scatter plot comparing basin area to active-channel width for all 52 sites measured in the Salt Basin, N. Mex. 


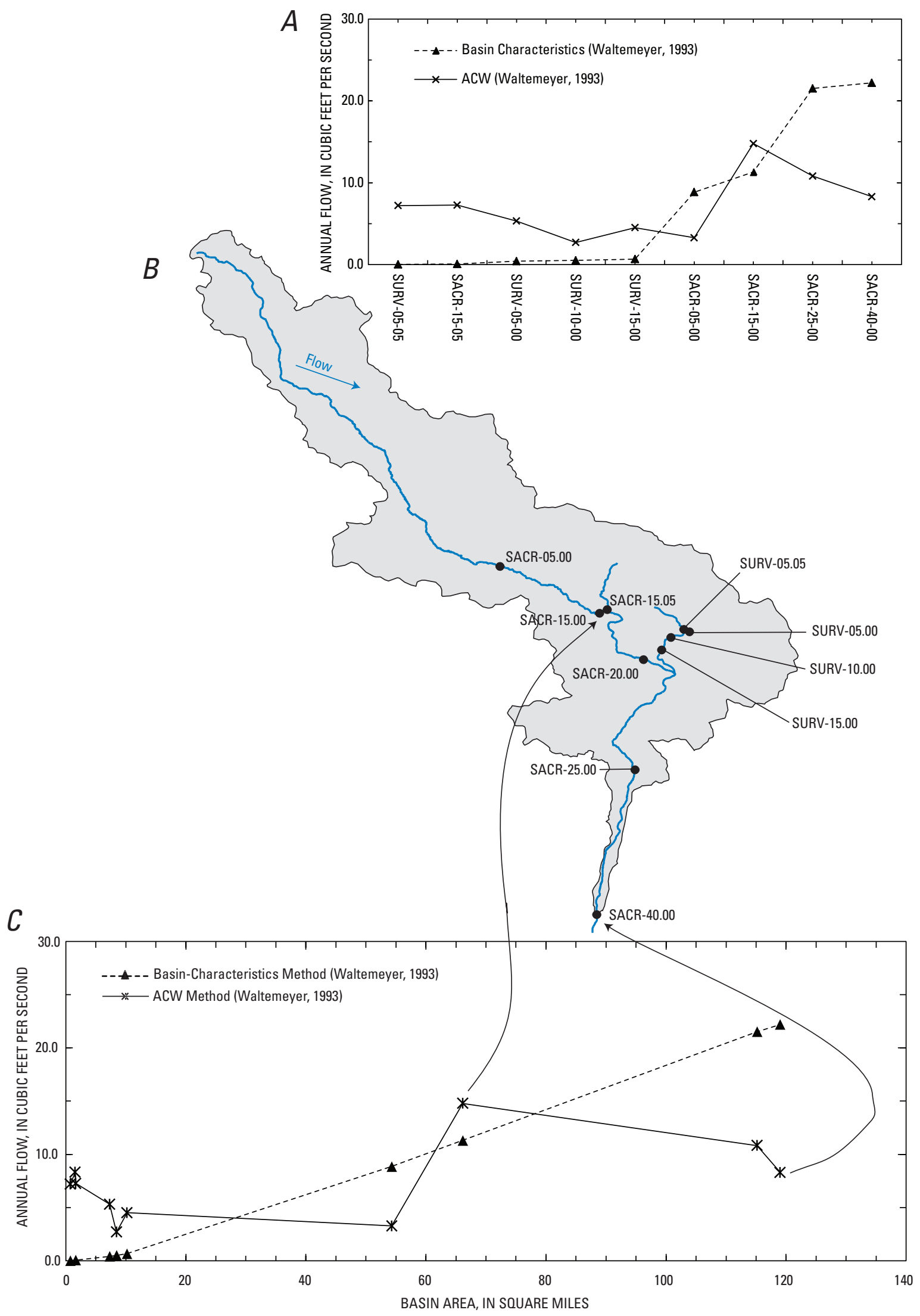

Figure 6. $A$, Estimates of mean-annual streamflow for each Sacramento River, N. Mex., subbasin site displayed categorically by increasing basin area (ACW, active-channel width). B, Sacramento River subbasin (see fig. 1). C, Trends of mean-annual streamflow estimates compared to basin area for the two methods used at the study sites in the Sacramento River, N. Mex., subbasin. 
Table 1. Sacramento River, N. Mex., active-channel widths and mean-annual streamflow estimates.

[ACW, active-channel width; $\mathrm{ft}^{3} / \mathrm{s}$, cubic feet per second]

\begin{tabular}{|c|c|c|c|c|}
\hline Site (see fig. 6) & ACW, in feet & $\begin{array}{c}\text { Annual flow in } \mathrm{ft}^{3} / \mathrm{s}, \\
\text { Waltemeyer (1993) ACW } \\
\text { method (standard error: } \\
29 \text { percent) }\end{array}$ & $\begin{array}{l}\text { Annual flow in } \mathrm{ft}^{3} / \mathrm{s} \text {, Kunkler } \\
\text { and Scott ACW method (in } \\
\text { Waltemeyer, 1993) (standard } \\
\text { error: } 82 \text { percent) }\end{array}$ & $\begin{array}{c}\text { Annual flow in } \mathrm{ft}^{3} / \mathrm{s} \text {, } \\
\text { Waltemeyer (1993) } \\
\text { basin-characteristics } \\
\text { method (standard error: } \\
46 \text { percent) }\end{array}$ \\
\hline SURV-05.05 & 26 & 7.2 & 10 & ${ }^{1} 0.02$ \\
\hline SACR-15.05 & 26 & 7.3 & 10 & ${ }^{1} 0.07$ \\
\hline SURV-05.00 & 22 & 5.3 & 9.4 & ${ }^{1} 0.42$ \\
\hline SURV-10.00 & 14 & 22.7 & 7.4 & ${ }^{1} 0.52$ \\
\hline SURV-15.00 & 20 & 4.5 & 8.9 & ${ }^{1} 0.67$ \\
\hline SACR-05.00 & 16 & 3.3 & 7.9 & 8.9 \\
\hline SACR-15.00 & 41 & 15 & 14 & 11 \\
\hline SACR-25.00 & 34 & 11 & 12 & 22 \\
\hline SACR- 40.00 & 29 & 8.3 & 11 & 22 \\
\hline
\end{tabular}

The maximum active-channel-width measurement was at site SACR-15.00 on the main stem of the Sacramento River, 16 stream miles upstream from the most downstream channel section measured. The active-channel width at SACR-15.00 was $41 \mathrm{ft}$, which corresponds to a mean-annual streamflow of $15 \mathrm{ft}^{3} / \mathrm{s}$ or $10,866 \mathrm{acre}-\mathrm{ft} / \mathrm{yr}$ (fig. 6). This mean-annual streamflow is 81 percent higher than mean-annual streamflow calculated at the most downstream measurement site for the active-channel-width method, SACR-40.00. The activechannel width at SACR-40.00 is $29 \mathrm{ft}$, which corresponds to a mean-annual streamflow of $8.3 \mathrm{ft}^{3} / \mathrm{s}$ or 6,013 acre-ft/yr.

\section{Cornucopia Draw Subbasin}

The active-channel width was measured at eight locations on Cornucopia Draw (fig. 7), two locations on the Fleming Draw tributary, one location on the New Tank Draw tributary, and four other locations on tributaries of Cornucopia Draw (fig. 7). The active-channel widths and annual-flow estimates for Cornucopia Draw subbasin are presented in table 2. The maximum active-channel width occurred at site COPA40.00 , which is 26.4 stream miles upstream from the most downstream section measured (COPA-70.00).

The maximum active-channel width at COPA- 40.00 was $51 \mathrm{ft}$, which corresponds to a mean-annual streamflow of $21 \mathrm{ft}^{3} / \mathrm{s}$ or 15,212 acre-ft/yr. This annual flow is 126 percent higher than the annual flow calculated at the most downstream channel section measured (see fig. 7, COPA-70.00), which had an active-channel width of $31 \mathrm{ft}$ corresponding to a meanannual streamflow of $9.3 \mathrm{ft}^{3} / \mathrm{s}$ or $6,737 \mathrm{acre}-\mathrm{ft} / \mathrm{yr}$.

\section{Piñon Creek Subbasin}

In the Piñon Creek subbasin (fig. 8), the active-channel width was measured at six locations on the main stem of the channel and at two additional tributaries. The active-channel widths and mean-annual streamflow estimates for the Piñon Creek subbasin are presented in table 3. The maximum active-channel width occurred at site PINO-60.00, which is 15 stream miles upstream from the most downstream section measured (PINO-70.00).

The maximum active-channel width at PINO-60.00 was $78 \mathrm{ft}$, which corresponds to a mean-annual streamflow of $41 \mathrm{ft}^{3} / \mathrm{s}$ or $29,700 \mathrm{acre}-\mathrm{ft} / \mathrm{yr}$. This annual flow is 37 percent higher than the annual flow calculated at the most downstream channel section measured (PINO-70.00) (see fig. 8), which had an active-channel width of $64 \mathrm{ft}$ corresponding to an annual flow of $30 \mathrm{ft}^{3} / \mathrm{s}$ or $21,732 \mathrm{acre}-\mathrm{ft} / \mathrm{yr}$.

\section{Big Dog Canyon Subbasin}

In Big Dog Canyon (fig. 1), the active-channel width was measured at seven locations on the main stem of the channel and at two additional sites in Box Canyon adjacent to the area north of Big Dog Canyon. As with the other three basins previously discussed, considerable effort was taken in the field to find suitable locations for active-channel-width measurements in Big Dog Canyon. There were, however, two specific challenges to distinguishing the active-channel widths in this subbasin (fig. 9). First, the channel beds were rarely flat and were usually sloping to one side. Second, sparse or moderate vegetation often covered the entire width of the channel. 


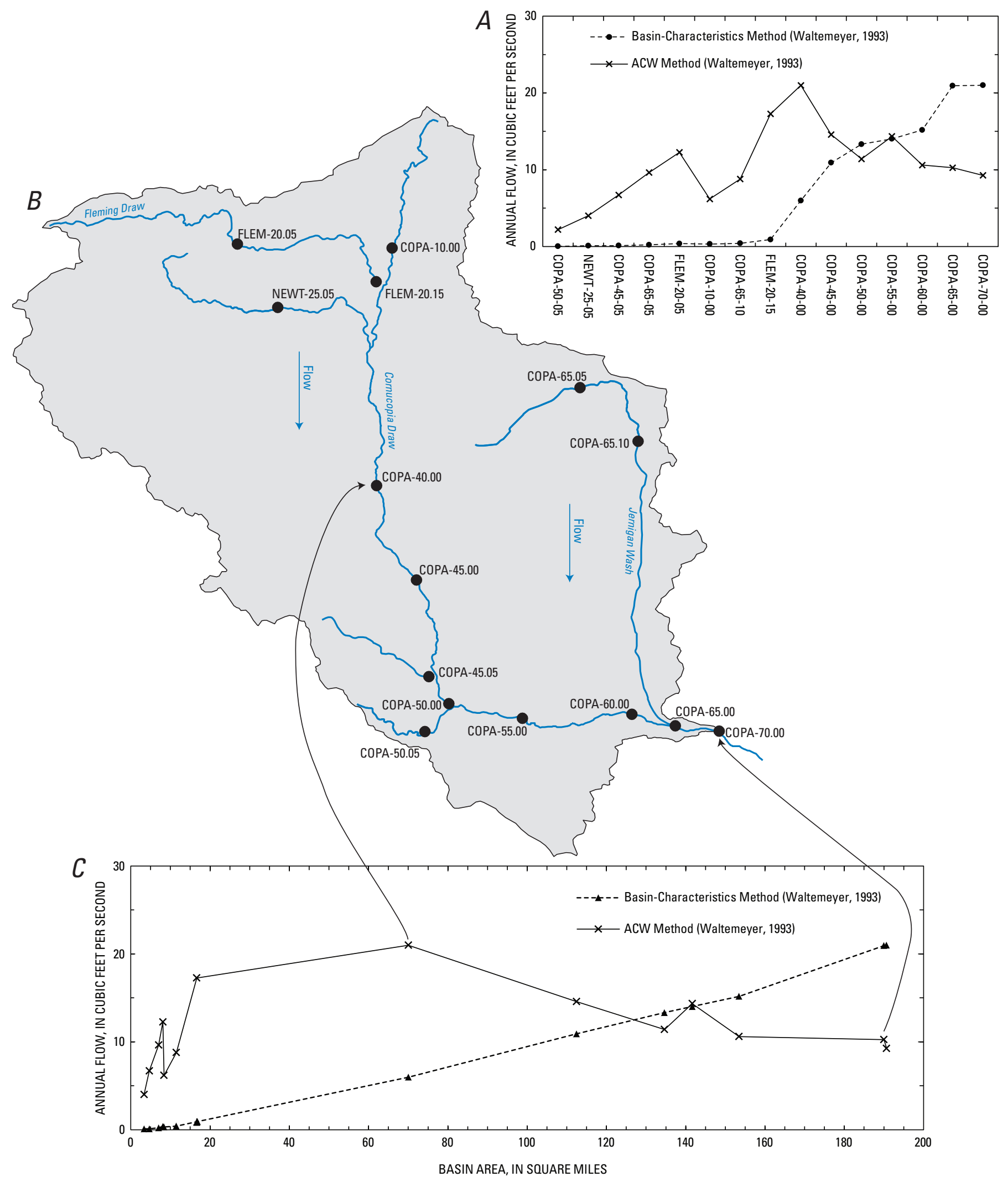

Figure 7. A, Estimates of mean-annual streamflow for each Cornucopia Draw, N. Mex., subbasin site displayed categorically by increasing basin area (ACW, active-channel width). B, Cornucopia Draw subbasin (see fig. 1). $C$, Trends of mean-annual streamflow estimates compared to basin area for the two methods used at the study sites in the Cornucopia Draw, N. Mex., subbasin. 


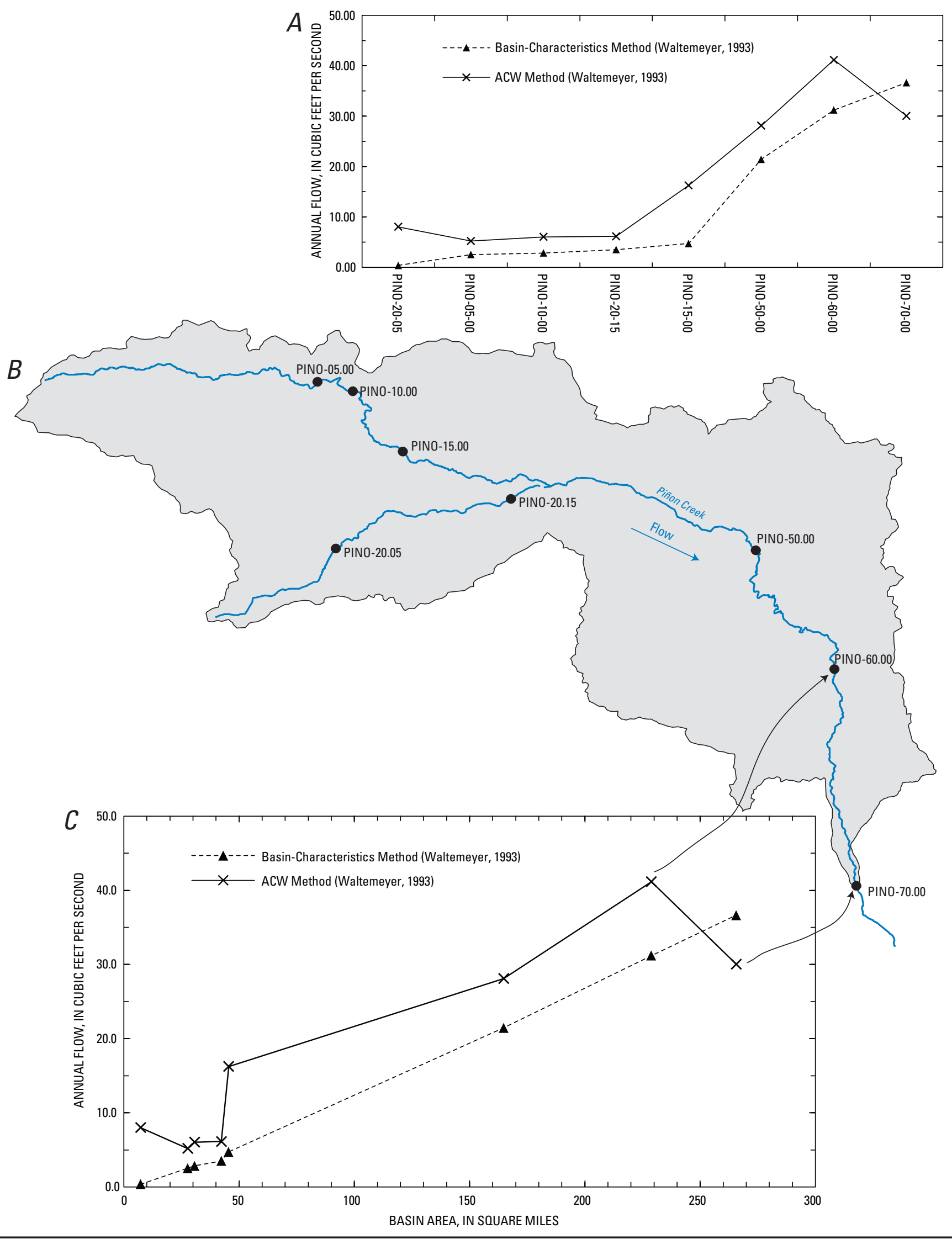

Figure 8. $\quad A$, Estimates of mean-annual streamflow for each Piñon Creek, N. Mex., subbasin site displayed categorically by increasing basin area (ACW, active-channel width). B, Piñon Creek subbasin (see fig. 1). $C$, Trends of mean-annual streamflow estimates compared to basin area for the two methods used at the study sites in the Piñon Creek, N. Mex., subbasin. 
Table 2. Cornucopia Draw, N. Mex., active-channel widths and mean-annual streamflow estimates.

$\left[\mathrm{ACW}\right.$, active-channel width; $\mathrm{ft}^{3} / \mathrm{s}$, cubic feet per second]

\begin{tabular}{|c|c|c|c|c|}
\hline Site (see fig. 7) & $A C W$, in feet & $\begin{array}{c}\text { Annual flow in } \mathrm{ft}^{3} / \mathrm{s} \text {, } \\
\text { Waltemeyer (1993) ACW } \\
\text { method (standard error: } \\
29 \text { percent) }\end{array}$ & $\begin{array}{c}\text { Annual flow in } \mathrm{ft}^{3} / \mathrm{s} \text {, } \\
\text { Kunkler and Scott ACW } \\
\text { method (in Waltemeyer, } \\
\text { 1993) (standard error: } \\
82 \text { percent) }\end{array}$ & $\begin{array}{c}\text { Annual flow in } \mathrm{ft}^{3} / \mathrm{s} \text {, } \\
\text { Waltemeyer (1993) } \\
\text { basin-characteristics } \\
\text { method (standard error: } \\
46 \text { percent) }\end{array}$ \\
\hline COPA-50.05 & 12 & 12.2 & 6.8 & ${ }^{2} 0.02$ \\
\hline COPA-65.05 & 31 & 9.6 & 12 & ${ }^{2} 0.22$ \\
\hline NEWT-25.05 & 18 & 4.0 & 8.5 & ${ }^{2} 0.10$ \\
\hline COPA-10.00 & 24 & 6.2 & 9.9 & ${ }^{2} 0.32$ \\
\hline COPA-65.10 & 30 & 8.8 & 11 & ${ }^{2} 0.41$ \\
\hline FLEM-20.05 & 37 & 12 & 13 & ${ }^{2} 0.38$ \\
\hline FLEM-20.15 & 45 & 17 & 15 & 0.91 \\
\hline COPA-55.00 & 40 & 14 & 14 & 14 \\
\hline COPA-60.00 & 33 & 11 & 12 & 15 \\
\hline COPA-65.00 & 33 & 10 & 12 & 21 \\
\hline COPA-70.00 & 31 & 9.3 & 12 & 21 \\
\hline
\end{tabular}

${ }^{1}$ Active-channel width is outside the range for which the equation was developed.

${ }^{2}$ Basin area is outside the range for which the equation was developed.

Table 3. Piñon Creek, N. Mex., active-channel widths and mean-annual streamflow estimates.

[ACW, active-channel width; $\mathrm{ft}^{3} / \mathrm{s}$, cubic feet per second]

\begin{tabular}{|c|c|c|c|c|}
\hline Site (see fig. 8) & $A C W$, in feet & $\begin{array}{l}\text { Annual flow in } \mathrm{ft}^{3} / \mathrm{s} \text {, } \\
\text { Waltemeyer (1993) ACW } \\
\text { method (standard error: } \\
29 \text { percent) }\end{array}$ & $\begin{array}{l}\text { Annual flow in } \mathrm{ft}^{3} / \mathrm{s} \text {, } \\
\text { Kunkler and Scott ACW } \\
\text { method (in Waltemeyer, } \\
\text { 1993) (standard error: } \\
82 \text { percent) }\end{array}$ & $\begin{array}{c}\text { Annual flow in } \mathrm{ft}^{3} / \mathrm{s} \text {, } \\
\text { Waltemeyer (1993) } \\
\text { basin-characteristics } \\
\text { method (standard error: } \\
46 \text { percent) }\end{array}$ \\
\hline PINO-20.05 & 28 & 8.0 & 11 & ${ }^{1} 0.37$ \\
\hline PINO-05.00 & 21 & 5.2 & 9.3 & 2.5 \\
\hline PINO-20.15 & 24 & 6.1 & 9.9 & 3.5 \\
\hline PINO-15.00 & 44 & 16 & 14 & 4.7 \\
\hline PINO-50.00 & 62 & ${ }^{2} 28$ & 17 & 21 \\
\hline PINO-60.00 & 78 & ${ }^{2} 41$ & 20 & 31 \\
\hline PINO-70.00 & 64 & ${ }^{2} 30$ & 18 & 37 \\
\hline
\end{tabular}

${ }^{1}$ Basin area is outside the range for which the equation was developed.

${ }^{2}$ Active-channel width is outside the range for which the equation was developed. 


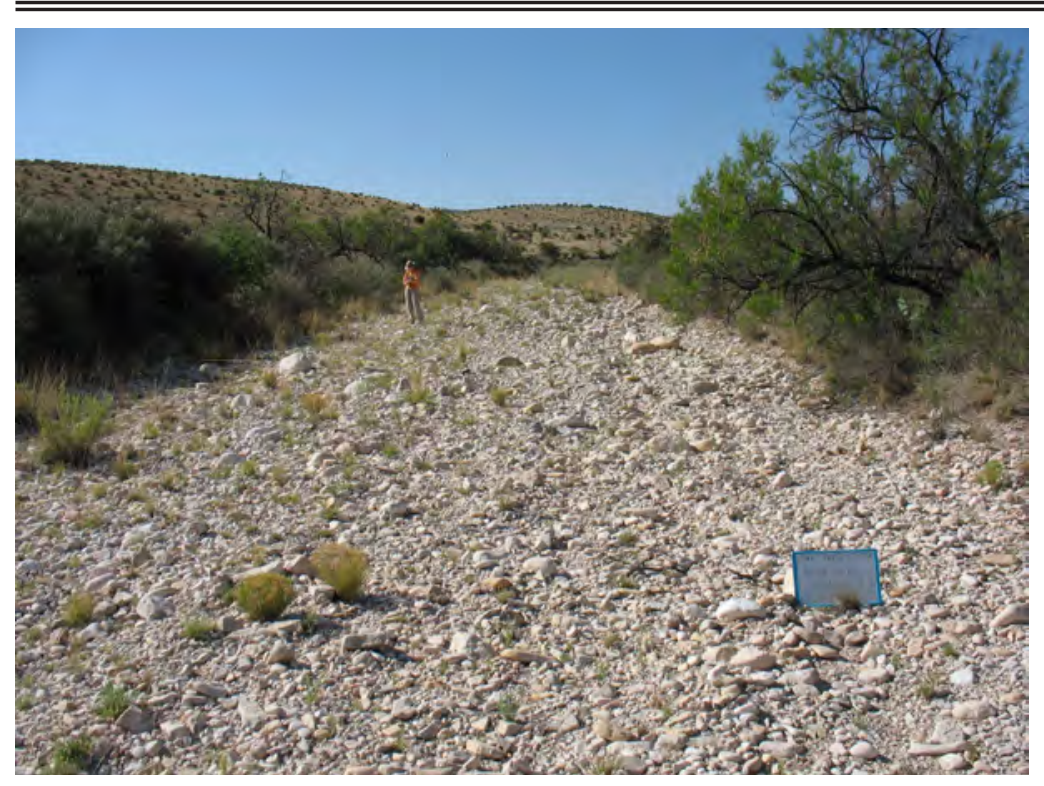

Figure 9. Typical Big Dog Canyon, N. Mex., channel section (BDOG-20.00 central cross section, facing upstream).

Proceeding in a downstream direction, the active-channel widths in Big Dog Canyon do not exhibit the trend of the other three subbasins where the active-channel widths increased gradually to a maximum value and then decreased towards the most downstream sections. The active-channel widths for Big Dog Canyon varied unpredictably with distance downstream. The difficulties in differentiating and measuring the active-channel widths in Big Dog Canyon account for the unpredictable variations in the active-channel widths with distance downstream. The active-channel widths and meanannual streamflow estimates for the Big Dog Canyon subbasin are presented in table 4.

The active-channel-width measurements made with the most confidence (because of the more classic channel geometry) are the tributary site in Box Canyon BDOG-50.02 and the main-stem sites BDOG-30.00 and BDOG-40.00. BDOG-40.00 has the maximum dependable active-channelwidth measurement in the Big Dog Canyon subbasin. The active-channel width at BDOG- 40.00 is $24 \mathrm{ft}$, which corresponds to a mean-annual streamflow of $6.4 \mathrm{ft}^{3} / \mathrm{s}$ or 4,636 acre-ft.

\section{Outlier Measurements}

Active-channel widths were measured in the field at several smaller tributaries unrelated to, or downstream from, the four main subbasins previously discussed. The activechannel widths and mean-annual streamflow estimates for the outlying subbasins are presented in table 5 . Three measurements were made on Chatfield Draw in Chatfield Canyon (fig. 1). Here again, the largest active-channel width of the three Chatfield Canyon sites measured was not the most downstream measurement but the middle measurement. The most downstream measurement (CHAT-15.00) had a stream length of $6.08 \mathrm{mi}$, and the site with the largest active-channel width (CHAT-10.00) had a stream length of $4.44 \mathrm{mi}$. The annual flow calculated for the maximum active-channel width in Chatfield Canyon is $9.2 \mathrm{ft}^{3} / \mathrm{s}$ or 6,664 acre- $\mathrm{ft}$.

Other outlier basins measured included three small basins on the western slopes of the Cornudas Mountains (CNDS), one measurement in a small $\left(0.3 \mathrm{mi}^{2}\right)$ basin near Big Dog Canyon called Crooked Canyon (CCAN), and one measurement in the northwestern part of the basin called Wildcat Draw (WILD) (fig. 1 and table 5). Two other downstream tributaries of the Sacramento River also were measured, but both canyons had irregular channels due to incision and bedrock outcrops, so these measurements were discarded. The measurements made in the Cornudas Mountains, Wildcat Draw, and Crooked Canyon subbasins were intended to expand the reach of the methods across the Salt Basin. Unfortunately, the active-channel widths and basin areas are too small in the Cornudas Mountains and Crooked Canyon subbasins to give reliable results with either the channel-geometry method or the basin-characteristics method. The measurement and subsequent calculations for Wildcat Draw are reliable, but because only one measurement was made in the entire draw, no information is available about the location of maximum flow or possible flow losses.

The USGS has continuously operated a peak-flow streamgage in the Fleming Draw tributary to Cornucopia Draw since 1959 (National Water Information System, 2009). This gage is designed to record only the peak gage height of floods and does not have a record applicable to calculating annual flow; however, the peak-flow record at the Fleming Draw streamgage does provide information on the timing of large rainfall events. There have been only 5 years with no flow at Fleming Draw since 1959. For the period 1959-2009, the gage recorded annual peak flows that were less than a 
Table 4. Big Dog Canyon, N. Mex., active-channel widths and mean-annual streamflow estimates.

$\left[\mathrm{ACW}\right.$, active-channel width; $\mathrm{ft}^{3} / \mathrm{s}$, cubic feet per second]

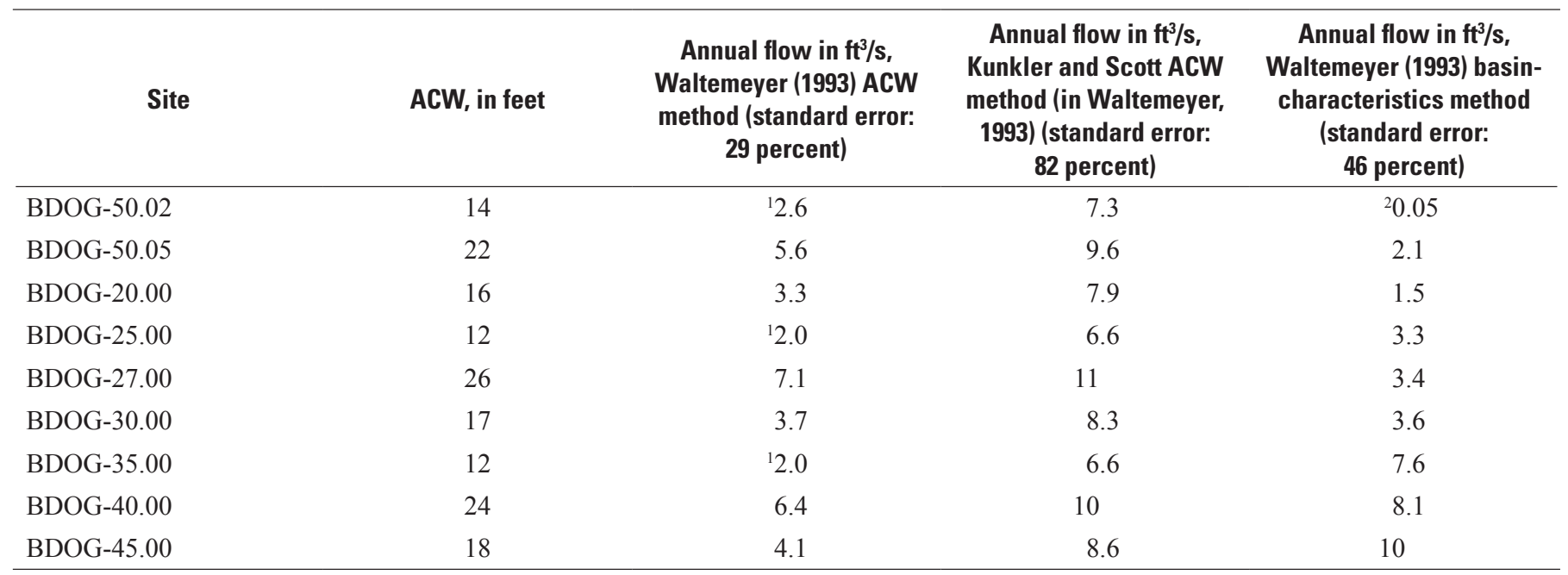

${ }^{1}$ Active-channel width is outside the range for which the equation was developed.

${ }^{2}$ Basin area is outside the range for which the equation was developed.

Table 5. Southeastern New Mexico outlier active-channel widths and mean-annual streamflow estimates.

[ACW, active-channel width; $\mathrm{ft}^{3} / \mathrm{s}$, cubic feet per second]

\begin{tabular}{|c|c|c|c|c|}
\hline Site & $A C W$, in feet & $\begin{array}{c}\text { Annual flow in } \mathrm{ft}^{3} / \mathrm{s} \text {, } \\
\text { Waltemeyer (1993) ACW } \\
\text { method (standard error: } \\
29 \text { percent) }\end{array}$ & $\begin{array}{l}\text { Annual flow in } \mathrm{ft}^{3} / \mathrm{s} \text {, } \\
\text { Kunkler and Scott ACW } \\
\text { method (in Waltemeyer, } \\
\text { 1993) (standard error: } \\
82 \text { percent) }\end{array}$ & $\begin{array}{l}\text { Annual flow in } \mathrm{ft}^{3} / \mathrm{s} \text {, } \\
\text { Waltemeyer (1993) basin- } \\
\text { characteristics method } \\
\text { (standard error: } \\
46 \text { percent) }\end{array}$ \\
\hline CHAT-05.00 & 18 & 4.0 & 8.5 & ${ }^{1} 0.08$ \\
\hline CHAT-10.00 & 42 & 15 & 14 & ${ }^{1} 0.71$ \\
\hline CNDS-05.00 & 16 & 3.1 & 7.7 & ${ }^{1} 0.07$ \\
\hline CNDS-05.05 & 11 & ${ }^{2} 1.8$ & 6.3 & ${ }^{1} 0.01$ \\
\hline CNDS-05.10 & 12 & ${ }^{2} 2.0$ & 6.6 & ${ }^{1} 0.03$ \\
\hline CCAN-20.05 & 7.4 & ${ }^{2} 0.97$ & 5.1 & ${ }^{1} 0.003$ \\
\hline WILD-20.00 & 29 & 8.5 & 11 & 0.36 \\
\hline
\end{tabular}

${ }^{1}$ Basin area is outside the range for which the equation was developed.

${ }^{2}$ Active-channel width is outside the range for which the equation was developed. 
small base level of flow during 12 years and recorded flood peaks during 28 years. Of the 28 years with flood peaks, the actual dates of the peaks were estimated by using Carlsbad, N. Mex., precipitation records 23 times. The dates of the 23 peak flows indicate a clear link to summer monsoonal precipitation patterns because 17 of the 23 recorded dates occurred in June, July, or August. The flow associated with the highest flood peak was $9,900 \mathrm{ft}^{3} / \mathrm{s}$, and it occurred in July 2006 .

\section{Comparison of Annual-Flow and Flow-Loss Estimates}

In all four of the main subbasins studied, active-channel widths achieved a maximum value some distance upstream of the most downstream section measured. Selected basin characteristics associated with the location of the maximum active-channel-width measurement in the four main subbasins measured are listed in table 6 .

Results from the Waltemeyer (1993) channel-geometry method, using the maximum active-channel-width values for each of the four main subbasins, indicate that, on average, an estimated 60,414 acre-ft of flow is generated annually among the four main subbasins, three of which are mountainfront subbasins, in the New Mexico part of the Salt Basin. These basins represent most of the mountain-front regions in the study area and 30 percent of the total Salt Basin area in New Mexico. The sum of the annual flows from the four basins evaluated could be considered a reasonable estimate of recharge for the New Mexico part of the Salt Basin, although subbasin areas not evaluated could contribute additional recharge to the Salt Basin, particularly in areas with karst (sink holes) and fractured rock. The standard error for this estimate is 29 percent. Results from the basin-characteristics method indicate a mean-annual streamflow of 65,196 acre-ft (standard error of estimate of 46 percent), which is comparable to the channel-geometry method. The important distinction between the basin-characteristics and channel-geometry estimates is not so much the volume but the location of the maximumflow estimates. The location of the maximum flow estimated from the basin-characteristics method is always calculated at the most downstream section measured, whereas the channelgeometry method indicated that the maximum flow occurs upstream from the most downstream section measured.

Active-channel width measurements indicate that each of the four main subbasin channels studied loses between 27 and 56 percent of annual flow from the point of maximum activechannel width to the most downstream measurable section in the channel. The flow losses are occurring over distances of 6.1-16.4 stream miles. The flow losses and associated distances for each of the four main subbasins studied are summarized in table 7. The basin-characteristics method is not useful in terms of identifying, quantifying, or locating flow losses along the length of a channel.

The active-channel-width method for estimating meanannual streamflow has traditionally been used at single locations on channels where estimates for annual flow are desired. The results of this study indicate that the activechannel-width method also has applications for estimating locations and quantities of flow losses when applied down the length of a channel. Each of the measurements for a channel was spaced several miles apart down the length of the stream. More detailed information on locations and amounts of flow accumulations and losses could possibly be obtained from closer spacing of sites down the length of a channel, but users are cautioned that measurements of channel width are subject to error and that the flow estimates also have considerable error as indicated by the standard errors of the regressions. More precisely, determining flow losses and their locations probably requires more accurate methods, such as gain-loss flow measurements, which can be challenging to acquire in these flashy systems.

Table 6. Basin characteristics associated with location of maximum active-channel width in each of the main subbasins measured in southeastern New Mexico.

[ACW, active-channel width; NAVD 88, North American Vertical Datum of 1988]

\begin{tabular}{lccccc}
\hline Subbasin (see fig. 1) & $\begin{array}{c}\text { Maximum ACW, } \\
\text { in feet }\end{array}$ & $\begin{array}{c}\text { Stream length, } \\
\text { in miles }\end{array}$ & $\begin{array}{c}\text { Basin area, } \\
\text { in square miles }\end{array}$ & $\begin{array}{c}\text { Elevation, in feet } \\
\text { above NAVD 88 }\end{array}$ & $\begin{array}{c}\text { Mean basin } \\
\text { elevation, in feet }\end{array}$ \\
\hline Sacramento River & 41 & 22.4 & 66.1 & 6,318 \\
Cornucopia Draw & 51 & 13.2 & 70.1 & 4,955 & 7,888 \\
Piñon Creek & 78 & 38.1 & 229 & 4,696 \\
Big Dog Canyon & 24 & 25.2 & 79.6 & 4,552 \\
\hline
\end{tabular}


Table 7. Flow losses and associated distances for the four main subbasins studied in southeastern New Mexico.

\begin{tabular}{|c|c|c|c|c|c|}
\hline $\begin{array}{l}\text { Subbasin } \\
\text { (see fig. 1) }\end{array}$ & $\begin{array}{l}\text { Maximum } \\
\text { annual-flow } \\
\text { estimate, } \\
\text { in acre-feet }\end{array}$ & $\begin{array}{l}\text { Most downstream } \\
\text { annual-flow } \\
\text { estimate, } \\
\text { in acre-feet }\end{array}$ & $\begin{array}{l}\text { Difference between } \\
\text { maximum annual } \\
\text { flow and } \\
\text { downstream annual } \\
\text { flow, in acre-feet }\end{array}$ & $\begin{array}{l}\text { Flow loss, } \\
\text { in percent }\end{array}$ & $\begin{array}{l}\text { Stream miles over } \\
\text { which losses occur }\end{array}$ \\
\hline Sacramento River & 10,866 & 6,013 & 4,853 & 45 & 16.0 \\
\hline Cornucopia Draw & 15,212 & 6,737 & 8,475 & 56 & 16.4 \\
\hline Big Dog Canyon & 4,636 & 2,970 & 1,666 & 36 & 6.1 \\
\hline
\end{tabular}

\section{Summary}

As much as 57 million acre-feet (acre-ft) of groundwater may be stored in the subsurface of the New Mexico part of the Salt Basin in southern Otero County, N. Mex. Recharge to a system such as the Salt Basin aquifer can result largely from focused recharge of surface water in channels and at mountain fronts. The Salt Basin is a closed basin that covers about 2,400 square miles $\left(\mathrm{mi}^{2}\right)$ of southeastern New Mexico and extends across the State line into Texas. A graben underlies the east-central valley, which is buried by hundreds of feet of alluvial deposits. Bedrock that underlies the alluvial deposits and forms the surrounding plateaus is composed primarily of carbonate and mixed carbonate/evaporate units that can be karst forming in places. Karst and fractured-rock features in the downstream parts of some areas of the Salt Basin also may provide opportunities for substantial recharge. Annual recharge to an aquifer such as the Salt Basin aquifer is commonly estimated in groundwater models by mean-annual streamflow.

Mean-annual streamflow was estimated for four main subbasins, including three mountain-front subbasins, in the internally drained Salt Basin in southeastern New Mexico. These four main subbasins account for 30 percent of the Salt Basin area in New Mexico. Estimates of mean-annual streamflow were generated at multiple sites down the length of each basin by using two regional regression equations based on channel geometry and one based on the basin characteristics of area and precipitation. The channel-geometry method requires field measurements of active-channel width at carefully selected channel reaches. The possibility of making channel-geometry measurements remotely, by using aerial photographs to increase measurement density and project efficiency, was tested. Remote measurements of activechannel width correlated poorly with field measurements and were determined to be an unsuitable substitute for field data collection of active-channel widths.

Estimates of streamflow derived by the two methods were compared for the four main subbasins. Results from the channel-geometry method indicate that, on average, an estimated 60,414 acre-ft of flow, assumed to be available for potential recharge to the basin, is generated annually among the four main subbasins, including the three main mountainfront subbasins, in the New Mexico part of the Salt Basin. The standard error for this estimate is 29 percent. Results from the basin-characteristics method indicate a mean-annual streamflow of 65,196 acre-ft (standard error of estimate of 46 percent), which is comparable to the channel-geometry method.

The use of the channel-geometry method at multiple locations down the length of each channel also provided information on the locations of flow accumulation and losses. The important distinction between the basin-characteristics and channel-geometry estimates is not so much the volume but the location of the maximum-flow estimates. The location of the maximum flow estimated from the basin-characteristics method is always calculated at the most downstream section measured, whereas the channel-geometry method indicated that the maximum flow occurs upstream from the most downstream section measured. Channels measured achieved maximum active-channel widths from 6 to 16 stream miles upstream from the locations in which channels bifurcate and lose shape altogether in the lowlands of the internally drained basin. Active-channel-width measurements indicate that each of the four main subbasin channels studied loses between 27 and 56 percent of annual flow from the point of maximum active-channel width to the most downstream measurable section in the channel.

\section{References}

Anderholm, S.K., 2000, Mountain-front recharge along the eastern side of the middle Rio Grande Basin, central New Mexico: U.S. Geological Survey Water-Resources Investigations Report 00-4010, 36 p. 
Google Earth, 2009, Source measurements, accessed November 2009, at http://earth.google.com/.

Hedman, E.R., and Osterkamp, W.R., 1982, Streamflow characteristics related to channel geometry of streams in Western United States: U.S. Geological Survey Water-Supply Paper 2193, 17 p.

Hejl, H.R., 1980, Preliminary appraisal of ephemeralstreamflow characteristics as related to drainage area, active-channel width, and soils in northwestern New Mexico: U.S. Geological Survey Open-File Report 81-64, $15 \mathrm{p}$.

Huff, G.F., and Chace, D.A., 2006, Knowledge and understanding of the hydrogeology of the Salt Basin in south-central New Mexico and future study needs: U.S. Geological Survey Open-File Report 2006-1358, 17 p.

Livingston Associates and John Shomaker and Associates, 2002, Tularosa Basin and Salt Basin regional water plan 2000-2040 - executive summary: Carrizozo, N.M., South Central Mountain RD\&C Council, Inc., 33 p.

Moore, D.O., 1974, Estimating flood discharges in Nevada using channel-geometry measurements: Carson City, State of Nevada Highway Department, Hydrologic Report Number 1, $43 \mathrm{p}$.

National Water Information System (NWIS), 2009, USGS peak streamflow for New Mexico, accessed November 2009 at http://nwis.waterdata.usgs.gov/nm/nwis/peak.

Omang, R.J., Parrett, Charles, and Hull, J.A., 1983, Meanannual runoff and peak flow estimates based on channel geometry of streams in southeastern Montana: U.S. Geological Survey Water-Resources Investigations 82-4092, $33 \mathrm{p}$.
Parrett, Charles, Hull, J.A., and Omang, R.J., 1987, Revised techniques for estimating peak discharges from channel width in Montana: U.S. Geological Survey Water-Resources Investigations Report 87-4121, 34 p.

PRISM Climate Group, 2009, Prism Climate Group home page: Oregon State University, 1971-2000, 30-arcsec $(800 \mathrm{~m})$ precipitation normals, accessed November 2009 at http://prism.oregonstate.edu/products/matrix.phtml.

Wahl, K.L., 1977, Accuracy of channel measurements and the implications in estimating streamflow characteristics: U.S. Geological Survey Journal of Research, v. 5, no. 6, Nov.-Dec. p. 811-814.

Wahl, K.L., 1984, Evolution of the use of channel crosssection properties for estimating streamflow characteristics, in Meyer, E.L., ed., Selected papers in the hydrological science: U.S. Geological Survey Water-Supply Paper 2262, p. 53-66.

Waltemeyer, S.D., 1993, Methods for estimating streamflow at mountain fronts in southern New Mexico: U.S. Geological Survey Water-Resources Investigations Report 93-4213, 17 p.

Waltemeyer, S.D., 2001, Estimates of mountain-front streamflow available for potential recharge to the Tularosa Basin, New Mexico: U.S. Geological Survey Water-Resources Investigations Report 01-4013, 8 p. 



\section{Appendix. Data Collected in the Salt Basin, N. Mex.}

Table. Data collected in the Salt Basin, N. Mex.

[ACW, active-channel width; NAVD 88, North American Vertical Datum of 1988]

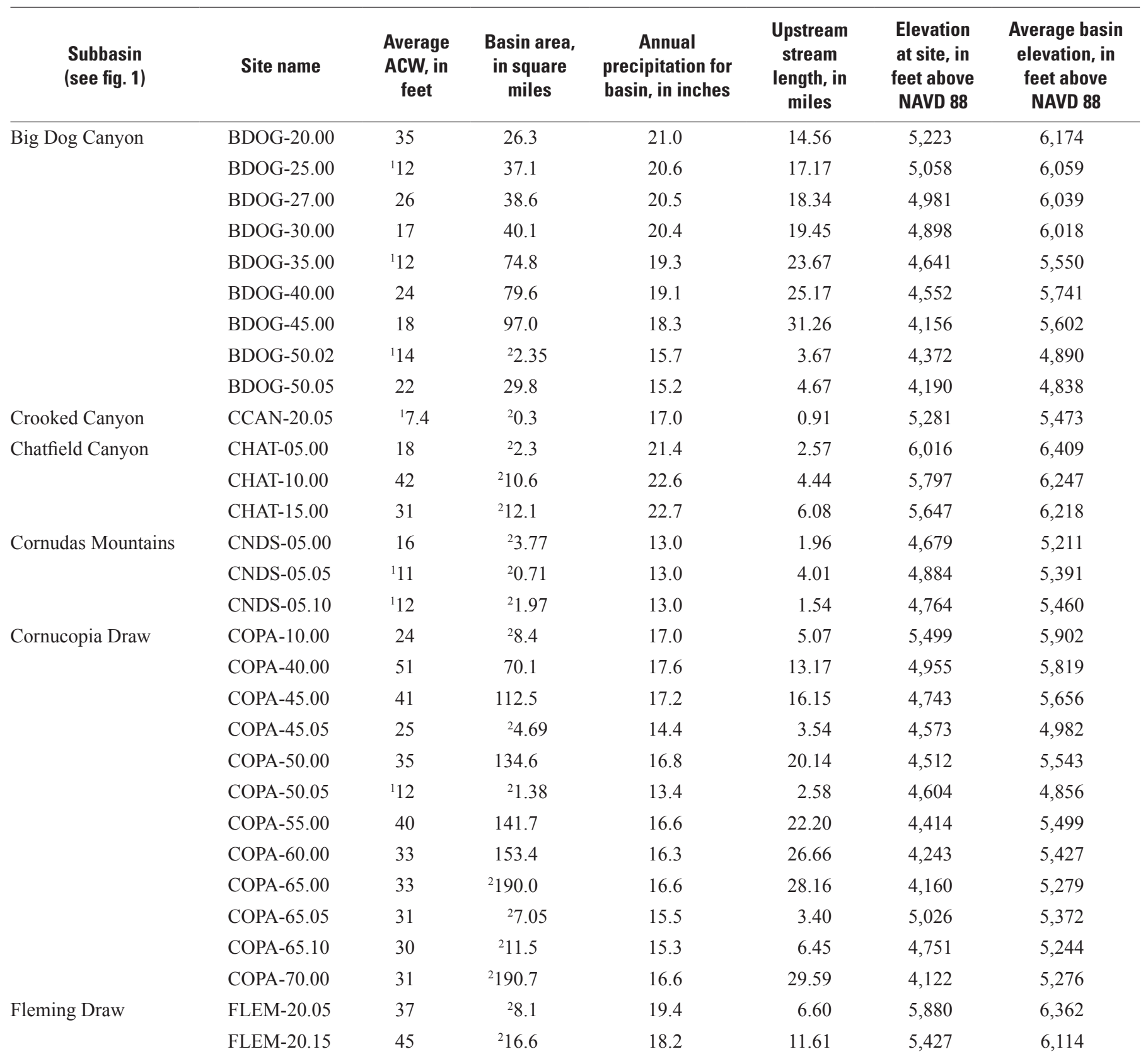


Table. Data collected in the Salt Basin, N. Mex.-Continued

[ACW, active-channel width; NAVD 88, North American Vertical Datum of 1988]

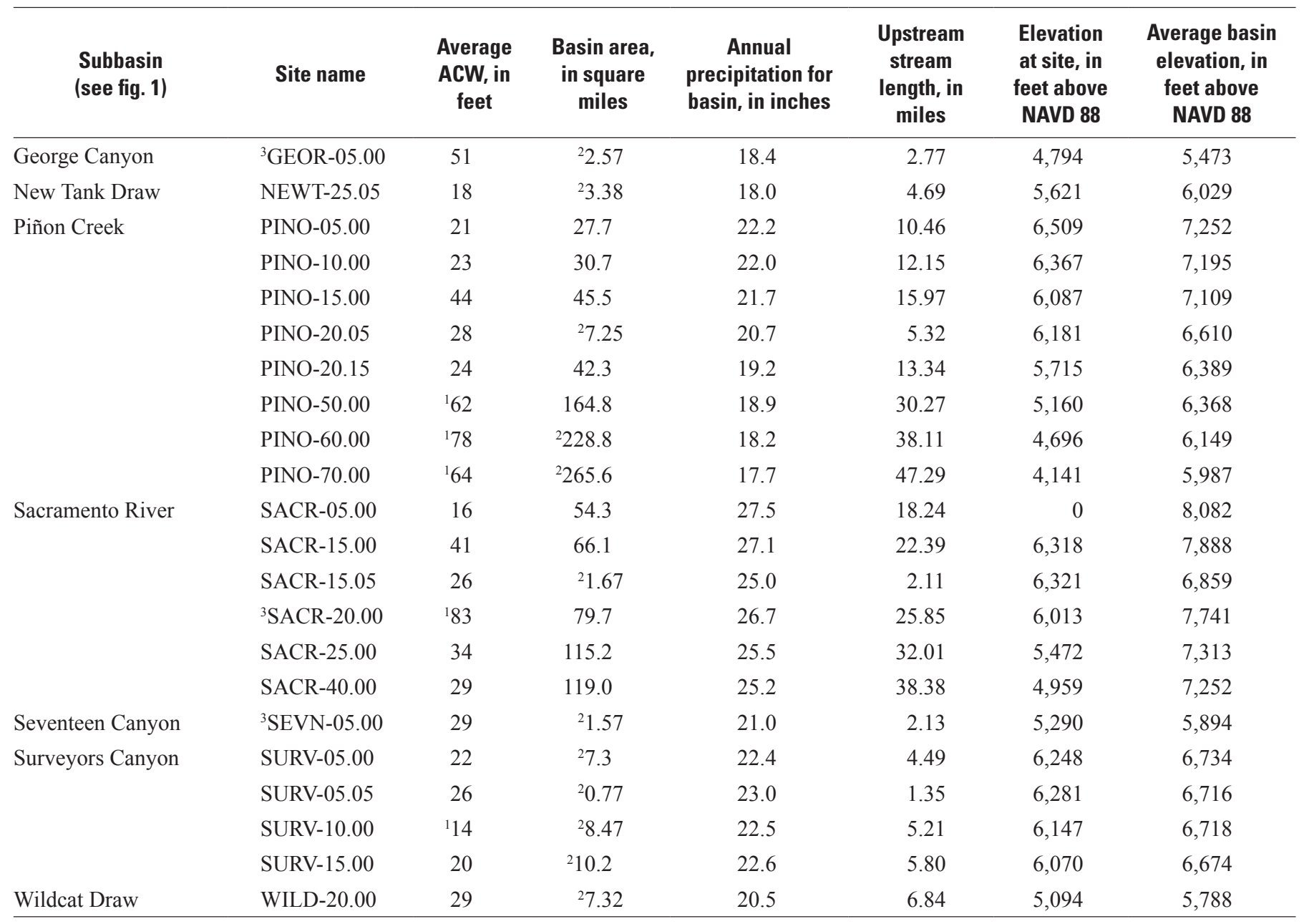

${ }^{1}$ Active-channel width is outside the range for which the equation was developed.

${ }^{2}$ Basin area is outside the range for which the equation was developed.

${ }^{3}$ Measurement is unreliable and excluded from analysis. 
